\title{
Risk Assessment of Physiological Effects of Atmospheric Composition and Pressure in Constellation Vehicles
}

Conkin $\mathrm{J}^{1}$, Jones JA${ }^{2}$, Scheuring RA ${ }^{3}$, Mike Gernhardt ${ }^{2}$ Universities Space Research Association ${ }^{1}$, NASA / Johnson Space Center / SD/SK ${ }^{2}$, Wyle Laboratories, Life

Sciences, Systems, and Services ${ }^{3}$ Houston, Texas, USA 77058.

Introduction: To limit the risk of fire and reduce denitrogenation time to prevent decompression sickness to support frequent extravehicular activities on the Moon, a hypobaric $\left(\mathrm{P}_{\mathrm{B}}=414 \mathrm{mmHg}\right)$ and mildly hypoxic $\left(\mathrm{ppO}_{2}=132 \mathrm{mmHg}, 32 \% \mathrm{O}_{2}-68 \%\right.$ $\mathrm{N}_{2}$ ) living environment is considered for the Crew Exploration Vehicle (CEV) and Lunar Surface Access Module (LSAM). With acute change in ppO2 from 145-178 mmHg at standard vehicular operating pressure to less than $125 \mathrm{mmHg}$ at desired lunar surface vehicular operating pressures, there is the possibility that some crewmembers may develop symptoms of Acute Mountain Sickness (AMS). The signs and symptoms of AMS (headache plus nausea, dizziness, fatigue, or sleeplessness), could impact crew health and performance on lunar surface missions. Methods: An exhaustive literature review on the topic of the physiological effects of reduced ppO2 and absolute pressure as may contribute to the development of altitude symptoms or AMS. The results of the nine most rigorous studies were collated, analyzed and contents on AMS and hypoxia symptoms summarized. Results: There is evidence for an absolute pressure effect per se on AMS, so the higher the altitude for a given hypoxic alveolar $\mathrm{O}_{2}$ partial pressure $\left(\mathrm{P}_{\mathrm{A}} \mathrm{O}_{2}\right)$, the greater the AMS response. About $25 \%$ of adults are likely to experience mild AMS near 2,000 $\mathrm{m}$ altitude following a rapid ascent from sea level while breathing air (6,500 feet, acute $\mathrm{P}_{\mathrm{A}} \mathrm{O}_{2}=75 \mathrm{mmHg}$ ). The operational experience with the Shuttle staged denitrogenation protocol at $528 \mathrm{mmHg}(3,048 \mathrm{~m})$ while breathing $26.5 \% \mathrm{O}_{2}$ (acute $\mathrm{P}_{\mathrm{A}} \mathrm{O}_{2}=85 \mathrm{mmHg}$ ) in astronauts adapting to microgravity suggests a similar likely experience in the proposed CEV environment. Conclusions: We believe the risk of mild AMS is greater given a $\mathrm{P}_{\mathrm{A}} \mathrm{O}_{2}$ of $77 \mathrm{mmHg}$ at $4,876 \mathrm{~m}$ altitude while breathing $32 \% \mathrm{O}_{2}$ than at $1,828 \mathrm{~m}$ altitude while breathing $21 \% \mathrm{O}_{2}$. Only susceptible astronauts would develop mild and transient AMS with prolonged exposure to $414 \mathrm{mmHg}(4,876 \mathrm{~m})$ while breathing $32 \% \mathrm{O}_{2}$ (acute $\mathrm{P}_{\mathrm{A}} \mathrm{O}_{2}=77 \mathrm{mmHg}$ ). So the following may be employed for operational risk reduction: 1) develop procedures to increase $\mathrm{P}_{\mathrm{B}}$ as needed in the $\mathrm{CEV}$, and use a gradual or staged reduction in cabin pressure during lunar outbound; 2) train crews for symptoms of hypoxia, to allow early recognition and consider pre-adaptation of crews to a hypoxic environment prior to launch, 3) consider prophylactic acetazolamide for acute pressure changes and be prepared to treat any AMS associated symptoms early with both carbonic anhydrase inhibitors and supplemental oxygen. 


\title{
Risk Assessment of Physiological Effects of Atmospheric Composition and Pressure in Constellation Vehicles
}

Richard A. Scheuring, DO, MS

\author{
Lead Flight Surgeon
}

Constellation Program

NASA / JSC 
NASA Acknowledgements

- Johnny Conkin, PhD, Jeff Jones, MD, Mike Gernhardt, PhD

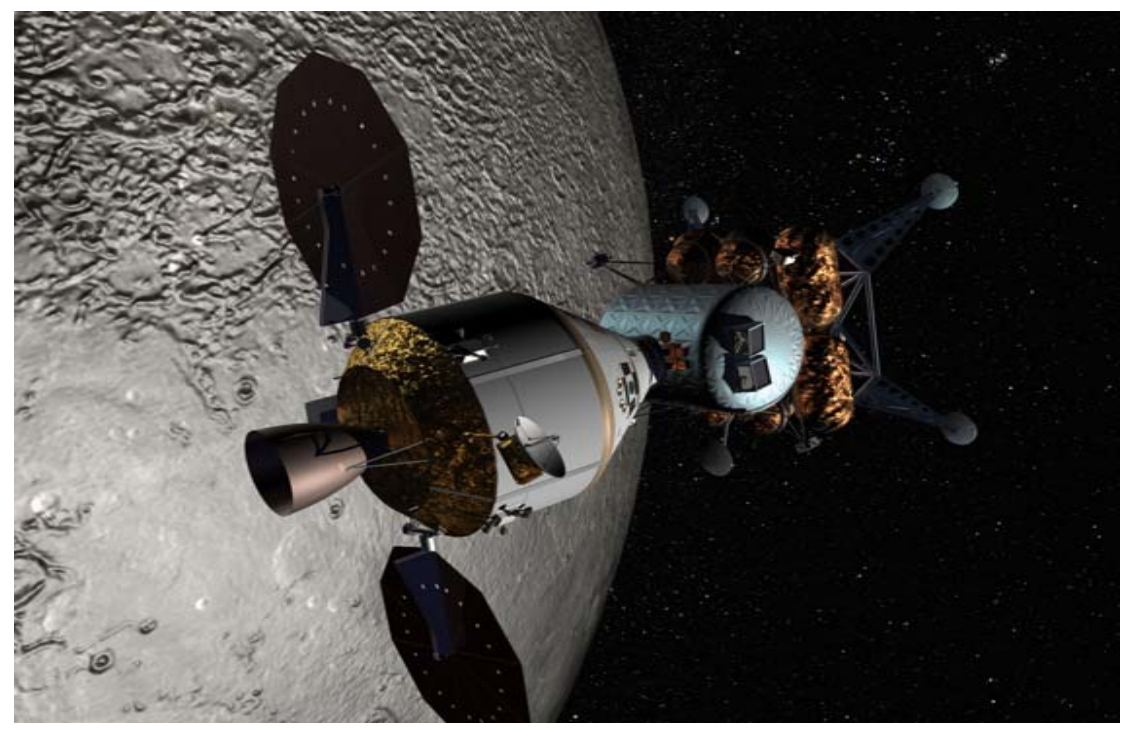




\section{Background}

- Atmosphere Design Considerations:

- Limit Hypoxia.

- Reduce Risk of Fire

- Prevent Decompression Sickness (DCS) and Venous Gas Emboli (VGE).

- Optimization of atmosphere(s) design to allow safe and efficient EVAs.

- Risks addressed:

- Mitigate risk of significant hypoxia.

- Mitigate / eliminate risk of serious DCS and VGE during EVA.

- Better to prevent rather than treat DCS, or to constantly embolize the lung.

- Underlying Assumptions:

- Efficient and frequent EVAs drive the exploration initiative.

- Low pressure suit is always preferred to high pressure suit.

- There is an operational value to a short in-suit prebreathe.

- Vehicle atmosphere may not prevent risk of DCS during EVA.

- Shuttle and ISS atmospheres are examples.

- Dedicated hyperbaric treatment capability may not be present. 


\section{Historical Spacecraft Atmospheres}

(From Lange, et al, 2005)

\begin{tabular}{|c|c|c|c|c|c|}
\hline Program & $\begin{array}{l}\text { Cabin } \\
\text { Pressure, } \\
\text { kPa (psia) }\end{array}$ & $\begin{array}{c}\text { Cabin Oxygen } \\
\text { Concentration, } \\
\text { volume \% }\end{array}$ & $\begin{array}{c}\text { EVA Suit } \\
\text { Pressure,(1) } \\
\text { kPa (psia) }\end{array}$ & $\begin{array}{c}\text { EVA } \mathrm{O}_{2} \text { Pre- } \\
\text { breathe Time, } \\
\text { minutes }\end{array}$ & $\begin{array}{l}\text { EVA Prebreathe } \\
\text { Conditions }\end{array}$ \\
\hline Mercury & $34.5(5)$ & 100 & - & - & - \\
\hline Gemini/Apollo & $34.5(5)$ & 100 & $25.8(3.75)$ & 0 & - \\
\hline Skylab & $34.5(5)$ & 70 & $25.8(3.75)$ & 0 & - \\
\hline \multirow[t]{2}{*}{ Shuttle } & $70.3(10.2)$ & 26.5 & $29.6(4.3)$ & 40 & $\begin{array}{c}\text { In-suit (after } 36 \\
\text { hours at } 70.3 \mathrm{kPa})\end{array}$ \\
\hline & $101.3(14.7)$ & 21 & $29.6(4.3)$ & $240^{(3)}$ & In-suit \\
\hline \multirow[t]{2}{*}{ ISS/US } & \multirow[t]{2}{*}{$101.3(14.7)$} & \multirow[t]{2}{*}{21} & \multirow[t]{2}{*}{$29.6(4.3)$} & $120-140$ & $\begin{array}{l}\text { Mask and in-suit; } \\
\text { staged w/exercise }\end{array}$ \\
\hline & & & & $240^{(3)}$ & In-suit \\
\hline $\begin{array}{l}\text { Salyut, Mir, } \\
\text { ISS/Russian }\end{array}$ & $101.3(14.7)$ & 21 & $40.0(5.8)^{(2)}$ & 30 & In-suit \\
\hline
\end{tabular}

References: Carson, et al. (1975), McBarron, et al. (1993), Waligora, et al. (1993), NASA (2002), NASA (2003).

(1) $100 \%$ oxygen.

(2) In earlier versions of the Orlan suit, the pressure could be reduced to $26.5 \mathrm{kPa}$ (3.8 psia) for short-duration work regime.

(3) Under emergency conditions, a minimum of 150 minutes of unbroken prebreathe is recommended. 


\section{Future Spacecraft Atmospheres}

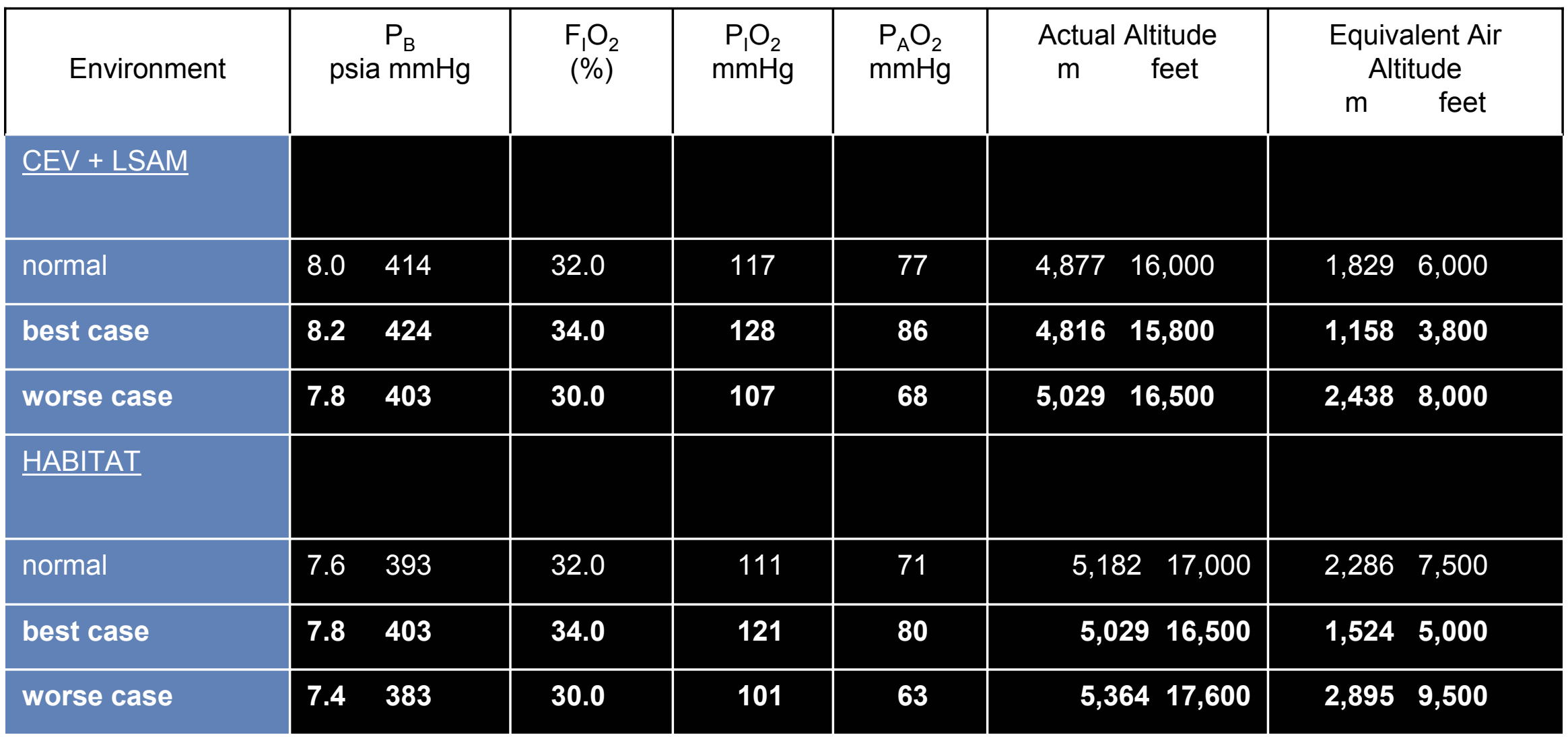

$\mathrm{P}_{1} \mathrm{O}_{2}$ is inspired $\mathrm{O}_{2}$ partial pressure, computed as $(\mathrm{PB} m \mathrm{mmg}-47){ }^{*} \mathrm{~F}_{1} \mathrm{O}_{2}$ (as decimal fraction).

PAO2 is computed acute alveolar oxygen partial pressure from alveolar oxygen equation. 


\section{Summary of Recommendations for Constellation Mission Systems}

\begin{tabular}{|c|c|c|c|c|c|}
\hline Vehicle & $\begin{array}{c}\text { Nominal } \\
\text { Total Pressure } \\
\quad(\text { psia } \\
+/-0.2 \text { psia })^{4}\end{array}$ & $\begin{array}{l}\text { Nominal Oxygen } \\
\text { Partial Pressure } \\
(\mathrm{mmHg})^{4}\end{array}$ & $\begin{array}{c}\text { Nominal Oxygen } \\
\text { Concentration } \\
(\% \\
+/-2.0 \%)^{4}\end{array}$ & $\begin{array}{c}\text { Range of Total } \\
\text { Pressure Capability } \\
\text { (psia) }{ }^{1}\end{array}$ & $\begin{array}{c}\text { Tissue Ratio ( R ) } \\
\text { After } 60 \text { Minutes } \\
\text { Prebreathing }\end{array}$ \\
\hline CEV to ISS & $\begin{array}{l}14.7 \\
10.2^{5}\end{array}$ & $\begin{array}{c}160(0 \mathrm{ft}) \\
140(3500 \mathrm{ft})\end{array}$ & $\begin{array}{c}21 \\
26.5\end{array}$ & $0-14.9$ & \\
\hline CEV In-Space Suit & 4.3 & 222 & 100 & $4.0-4.6$ & $\begin{array}{c}1.55 \text { from } 10.2 \text { psia } \\
\text { CEV to } 4.3 \text { psia } \\
\text { suit }\end{array}$ \\
\hline Lunar and Mars CEV & $\begin{array}{l}14.7 \\
10.2\end{array}$ & $\begin{array}{c}160(0 \mathrm{ft}) \\
140(3500 \mathrm{ft})\end{array}$ & $\begin{array}{c}21 \\
26.5\end{array}$ & $0-14.9$ & \\
\hline Lunar and Mars Landers & $\begin{array}{c}10.2 \\
8.0\end{array}$ & $\begin{array}{l}140(3500 \mathrm{ft}) \\
132(5000 \mathrm{ft})\end{array}$ & $\begin{array}{c}26.5 \\
32\end{array}$ & $0-14.9$ & \\
\hline Lunar and Mars Surface Suits & $\begin{array}{l}4.3 \\
6.0\end{array}$ & $\begin{array}{l}222 \\
310\end{array}$ & $\begin{array}{l}100 \\
100\end{array}$ & $3.5-8.0^{2}$ & $\begin{array}{c}1.13 \text { from } 8.0 \text { psia } \\
\text { Landers to } 4.3 \\
\text { psia suit; } \\
1.07 \text { from } 7.6 \text { psia } \\
\text { Surface } \\
\text { Habitats to } 4.3 \\
\text { psia suit }\end{array}$ \\
\hline Lunar and Mars Surface Habitats & $\begin{array}{l}8.0 \\
7.6\end{array}$ & $\begin{array}{l}132(5000 \mathrm{ft}) \\
126(6500 \mathrm{ft})\end{array}$ & $\begin{array}{l}32 \\
32\end{array}$ & $0-14.9$ & \\
\hline Mars Transit & $\begin{array}{l}14.7 \\
10.2\end{array}$ & $\begin{array}{c}160(0 \mathrm{ft}) \\
140(3500 \mathrm{ft})\end{array}$ & $\begin{array}{c}21 \\
26.5\end{array}$ & $0-14.9$ & \\
\hline
\end{tabular}

Note 1: Range of total pressure capability covers Earth launch, Earth entry, and contingencies.

Note 2: Surface suit 3.5 psia capability for suit emergency operations, 8.0 psia for DCS treatment.

Note 3: 60 minute in-suit prebreathe is defined as the time in the suit after purge and leak check until

absolute pressure on the body reaches 4.3 psia after a nominal depressurization. Nitrogen is assumed diluent gas 6

Note 4: All nominal values are centers of control boxes assumed $+/-0.2$ psia total pressure, $+/-2 \%$ oxygen.

Note 5: 10.2 psia recommendation is based on Shuttle experience, for CEV contingency EVA preparation. 


\section{NASA Spacecraft Atmosphere Design Space}

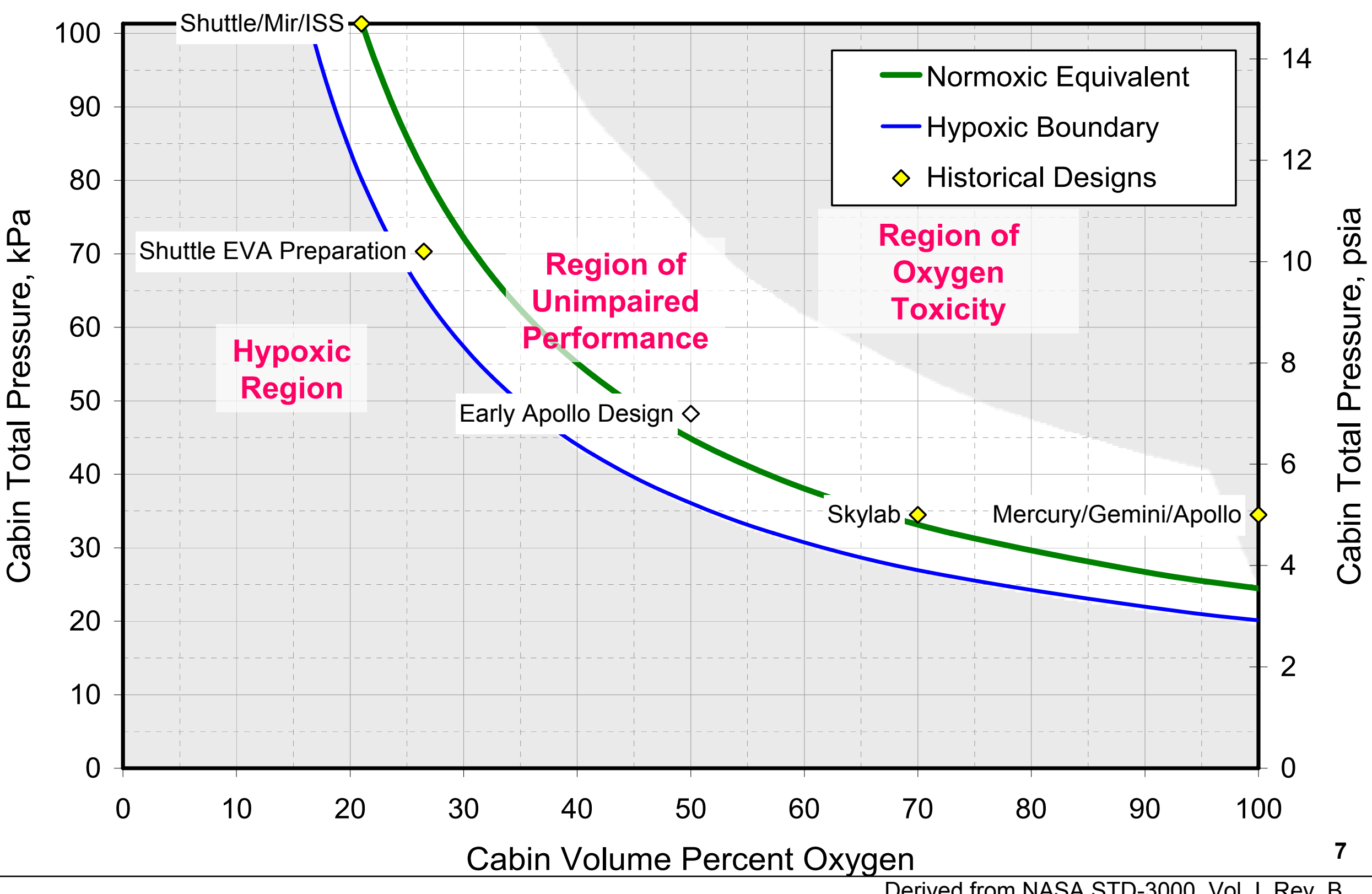




\section{NASA Spacecraft Atmosphere Design Space}

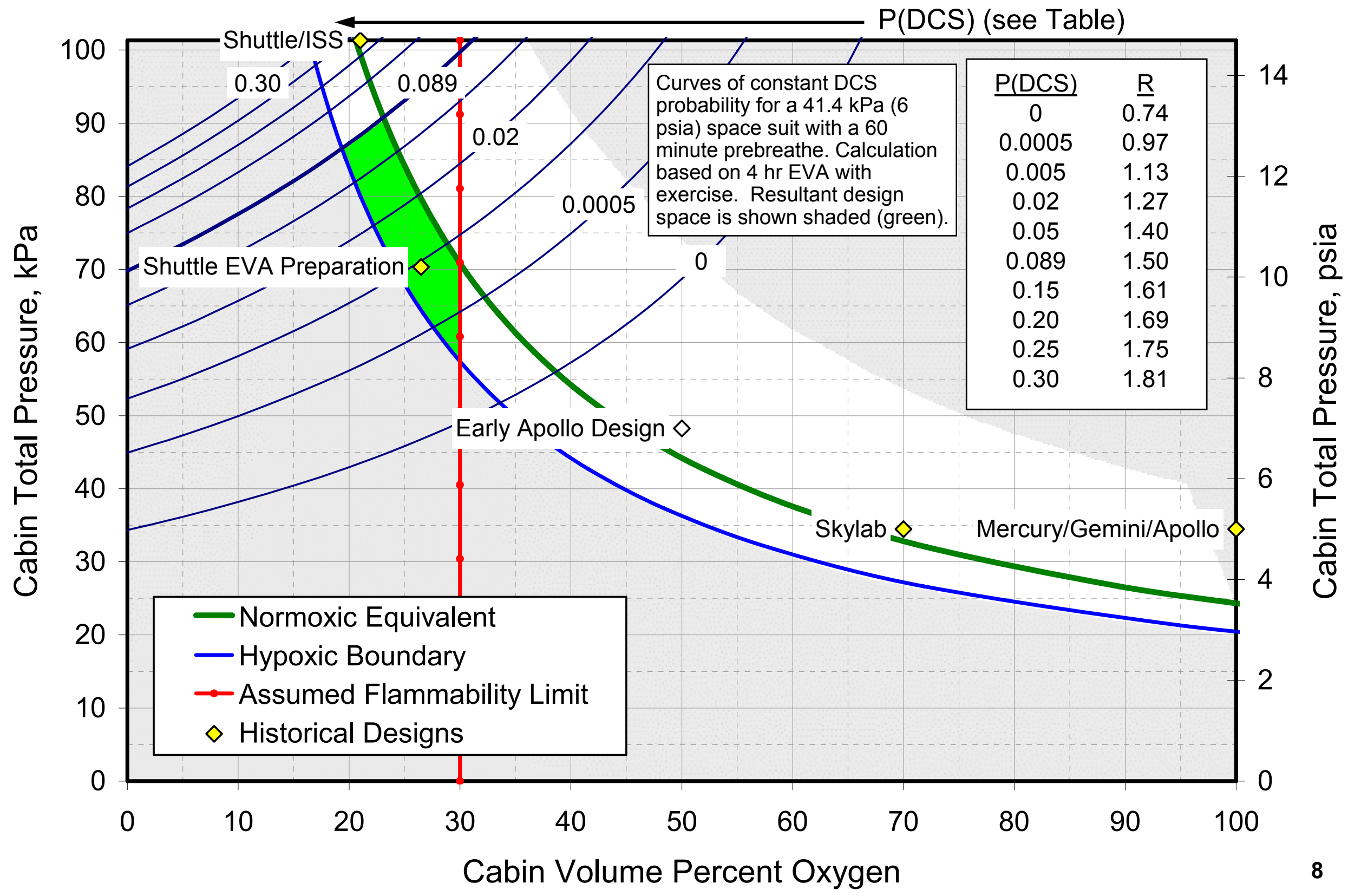

From NASA-CR-2005-213689, Lange, et al. 
Current EAWG Recommended Constellation Atmospheres

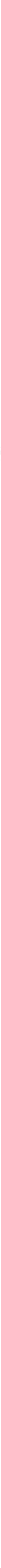




\section{Background and Rationale for Atmosphere Recommendations}

\section{- Hypoxia:}

- Aviation experience:

- Commercial airline cabins up to $8000 \mathrm{ft}$ without supplemental oxygen

- Military operations up to $10000 \mathrm{ft}$ without supplemental oxygen

- Space experience:

- All previous NASA programs were at $6000 \mathrm{ft}$ or lower

- ISS excursions per Flight Rule with time duration limits

- US Air Force research:

- Recently reported Brooks data show 8000 feet has minimal cognitive effect

- Decompression sickness:

- Space experience: no reported in-flight DCS for Shuttle/ISS (Apollo ascent report by one crewmember).

- Much zero-g experience, but little in hypogravity environments

- NASA ground testing shows higher DCS incidence than zero-g

- Expect that lunar gravity ambulation will have significantly higher risk than zero-g

- Flammability:

- Space experience: Apollo, Mir, Shuttle fire events

- Apollo-1: catastrophic outcome

- Mir-22 and Shuttle: non-catastrophic (materials usage controls, larger vehicles, much lower oxygen concentrations)

- Flammability threshold testing will give better materials characterization versus current pass/fail ${ }^{0}$ testing (NASA STD-6001 standard test). Characterization of pyrolysis products is also needed. 
- Ascent causes a decrease in $\mathrm{P}_{\mathrm{a}} \mathrm{O}_{2}$ sensed by the peripheral and central chemoreceptors, leading to increased rate of pulmonary ventilation $\left(V_{E}\right)$.

- Hyperventilation in response to hypoxia increases $P_{A} O_{2}$ and subsequently decreases alveolar carbon dioxide $\left(\mathrm{P}_{\mathrm{A}} \mathrm{CO}_{2}\right)$ and leads to a transient alkalosis.

- There is also a hypoxia-induced diuresis as the kidney attempts to return to a balanced $\mathrm{pH}$ with the excretion of bicarbonate. 


\begin{tabular}{|c|c|c|c|c|c|c|c|c|}
\hline \multicolumn{2}{|c|}{ Altitude } & \multicolumn{2}{|c|}{ Pressure } & \multirow{2}{*}{$\begin{array}{c}\text { Ambient } \\
\mathrm{Po}_{2} \\
\text { (mm } \mathrm{Hg} \text { ) }\end{array}$} & \multirow{2}{*}{$\begin{array}{c}\mathrm{PAO}_{2} \\
(\mathrm{~mm} \mathrm{Hg})\end{array}$} & \multirow{2}{*}{$\begin{array}{c}\mathrm{PACO}_{2} \\
(\mathrm{~mm} \mathrm{Hg})\end{array}$} & \multirow{2}{*}{$\begin{array}{c}\mathrm{PH}_{2} \mathrm{O} \\
(\mathrm{mm} \mathrm{Hg})\end{array}$} & \multirow{2}{*}{$\begin{array}{c}\text { Respiratory } \\
\text { Exchange } \\
\text { Ratio (R) }\end{array}$} \\
\hline (m) & (ft) & (PSIA) & (mm Hg) & & & & & \\
\hline \multicolumn{9}{|c|}{ Breathing Air } \\
\hline 0 & 0 & 14.69 & 759.97 & 159.21 & 103.0 & 40.0 & 47.0 & 0.85 \\
\hline 305 & 1000 & 14.17 & 733.04 & 153.57 & 98.2 & 39.4 & - & - \\
\hline 610 & 2000 & 13.66 & 706.63 & 148.04 & 93.8 & 39.0 & - & - \\
\hline 914 & 3000 & 13.17 & 681.23 & 142.72 & 89.5 & 38.4 & - & - \\
\hline 1219 & 4000 & 12.69 & 656.34 & 137.50 & 85.1 & 38.0 & - & - \\
\hline 1524 & 5000 & 12.23 & 632.46 & 132.50 & 81.0 & 37.4 & 47.0 & 0.87 \\
\hline 1829 & 6000 & 11.77 & 609.09 & 127.60 & 76.8 & 37.0 & - & - \\
\hline 2134 & 7000 & 11.34 & 586.49 & 122.87 & 72.8 & 36.4 & - & - \\
\hline 2438 & 8000 & 10.91 & 564.64 & 118.29 & 68.9 & 36.0 & - & - \\
\hline 2743 & 9000 & 10.50 & 543.31 & 113.82 & 65.0 & 35.4 & - & - \\
\hline 3048 & 10,000 & 10.10 & 522.73 & 109.51 & 61.2 & 35.0 & 47.0 & 0.90 \\
\hline 3353 & 11,000 & 9.72 & 502.92 & 105.36 & 57.8 & 34.4 & - & - \\
\hline 3658 & 12,000 & 9.34 & 483.36 & 101.26 & 54.3 & 33.8 & - & - \\
\hline 3962 & 13,000 & 8.99 & 464.82 & 97.38 & 51.0 & 33.2 & - & - \\
\hline 4267 & 14,000 & 8.63 & 446.53 & 93.55 & 47.9 & 32.6 & - & - \\
\hline 4572 & 15,000 & 8.29 & 429.01 & 89.88 & 45.0 & 32.0 & 47.0 & 0.95 \\
\hline 4877 & 16,000 & 7.96 & 411.99 & 86.31 & 42.0 & 31.4 & - & - \\
\hline 5182 & 17,000 & 7.65 & 395.73 & 84.50 & 40.0 & 31.0 & - & - \\
\hline 5486 & 18,000 & 7.34 & 379.73 & 79.55 & 37.8 & 30.4 & - & - \\
\hline 5791 & 19,000 & 7.05 & 364.49 & 76.36 & 35.9 & 30.0 & - & - \\
\hline 6096 & 20,000 & 6.76 & 349.50 & 73.22 & 34.3 & 29.4 & 47.0 & 1.00 \\
\hline 6401 & 21,000 & 6.48 & 335.28 & 70.24 & 33.5 & 29.0 & - & - \\
\hline 6706 & 22,000 & 6.21 & 321.31 & 67.31 & 32.8 & 28.4 & 47.0 & 1.05 \\
\hline 7010 & 23,000 & 5.95 & 307.85 & 64.49 & 32.0 & 28.0 & - & - \\
\hline 7315 & 24,000 & 5.70 & 294.89 & 61.78 & 31.2 & 27.4 & - & - \\
\hline 7620 & 25,000 & 5.46 & 282.45 & 59.17 & 30.4 & 27.0 & 47.0 & - \\
\hline \multicolumn{9}{|c|}{ Breathing $100 \%$ Oxygen* } \\
\hline 10,058 & 33,000 & 3.81 & 197.10 & 197.10 & 109 & 40 & 47.0 & - \\
\hline 10,973 & 36,000 & 3.30 & 170.94 & 170.94 & 85 & 38 & 47.0 & - \\
\hline 11,887 & 39,000 & 2.86 & 148.08 & 148.08 & 64 & 36 & 47.0 & - \\
\hline 12,192 & 40,000 & 2.73 & 141.22 & 141.22 & - & - & - & - \\
\hline 12,802 & 42,000 & 2.48 & 128.27 & 128.27 & 48 & 33 & 47.0 & - \\
\hline 13,716 & 45,000 & 2.15 & 111.25 & 111.25 & 34 & 30 & 47.0 & - \\
\hline 14,021 & 46,000 & 2.05 & 105.92 & 105.92 & 30 & 29 & 47.0 & - \\
\hline
\end{tabular}


- Increased catecholamines

$-\uparrow \mathrm{HR}$

$-\uparrow \mathrm{CO}$

- $\uparrow$ Venous Tone

- $\downarrow$ Plasma Volume

- $\downarrow$ Stroke Volume
- Transient $\uparrow$ in Pulmonary artery pressure

- $\mathrm{Hgb} / \mathrm{HCT}$, viscosity

- Shift of $\mathrm{O}_{2} / \mathrm{HgB}$ curve to left

- cellular changes 
- There is some confusion and overlap among the high altitude syndromes.

- A sudden ascent to high altitude can result in a rapid death from Acute Hypoxia while a more gradual ascent to the same altitude can result in AMS or no symptoms at all.

- Symptoms of AMS generally take a longer period of time to develop (hrs-days) and there is great variability among the population of those who are susceptible.

- Severe and prolonged forms of AMS may lead to High Altitude Pulmonary Edema (HAPE) and High Altitude Cerebral Edema (HACE) and death. 
- Based on this committee's recommendations:

- A diagnosis of AMS is based on a recent gain in altitude, at least several hours $(>2)$ at the new altitude, and the presence of headache and at least one of the following symptoms: gastrointestinal upset, fatigue or weakness, dizziness or lightheadedness and difficulty sleeping.

- A score of three points or greater on the AMS SelfReport questionnaire alone or in combination with the clinical assessment score is diagnostic of AMS. 
-Each question asked and the sum is calculated as the AMS self report score

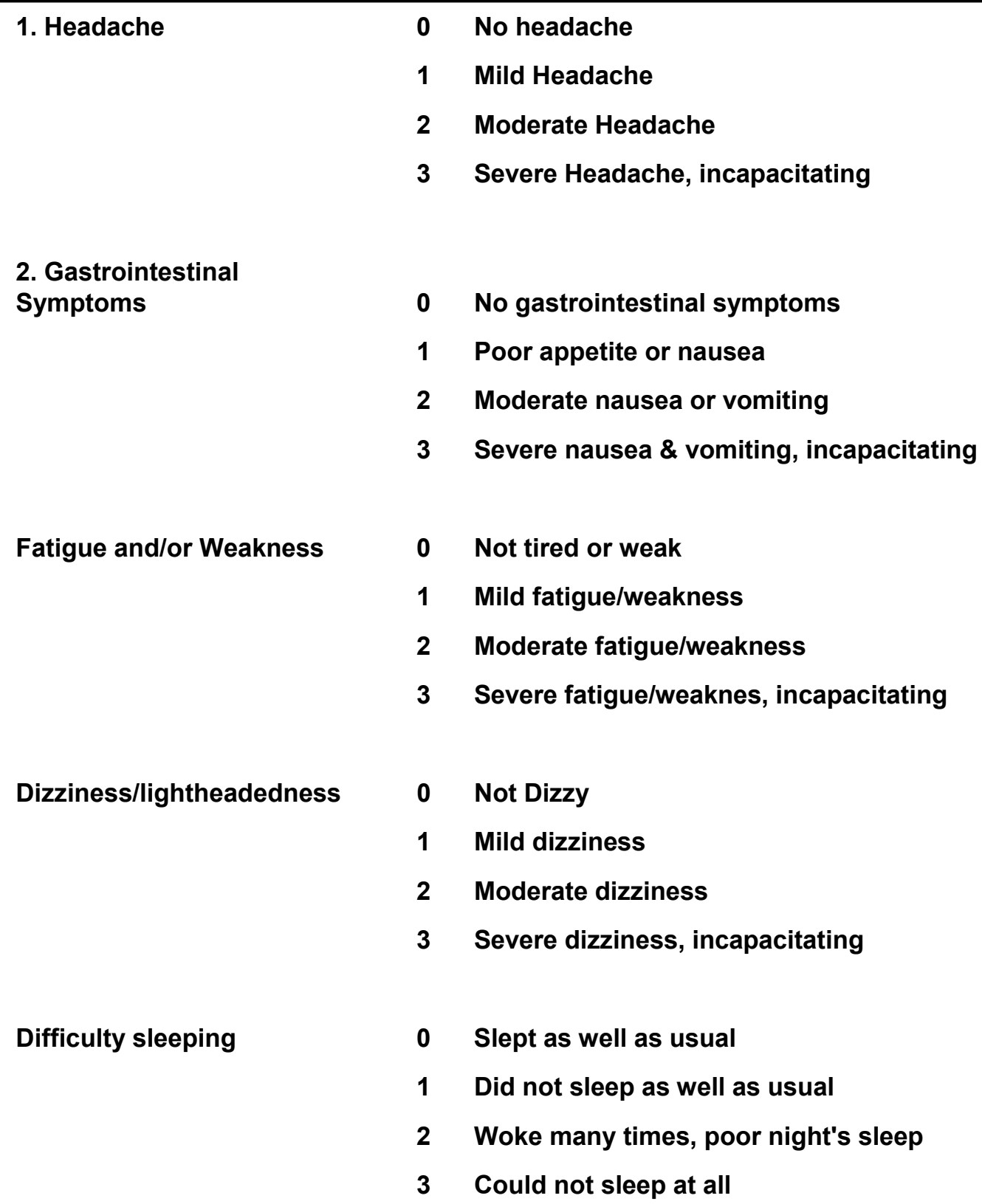

$0 \quad$ Slept as well as usual

1 Did not sleep as well as usual

2 Woke many times, poor night's sleep

3 Could not sleep at all 


\section{Clinical Assessment}

The interviewers ratings of three signs:

Added to the self-report score (Roach 1993)

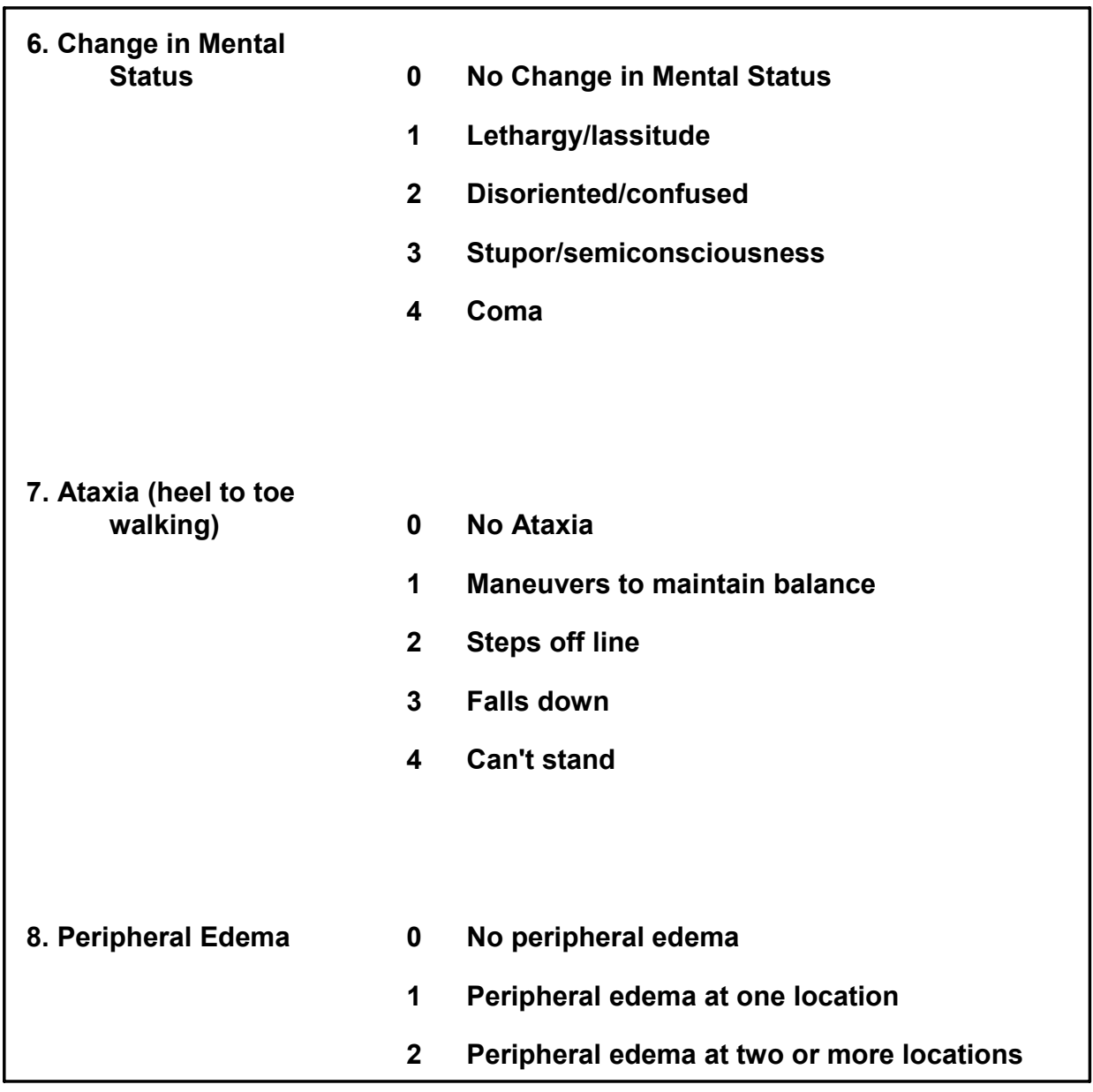

This system helped to standardize the diagnosis of AMS. 
- Despite over a century of research there remains a vigorous debate on the etiology and pathophysiology of AMS. 


\section{Paul Bert (1833-1886)}

- A French Physiologist considered the founder of Aerospace Medicine.

- Demonstrated, that the symptoms of AMS could be prevented or relieved by oxygen breathing and so

$$
\text { , that caused AMS. }
$$

- This doctrine that hypoxia alone is the cause for AMS has held true for 150 years.

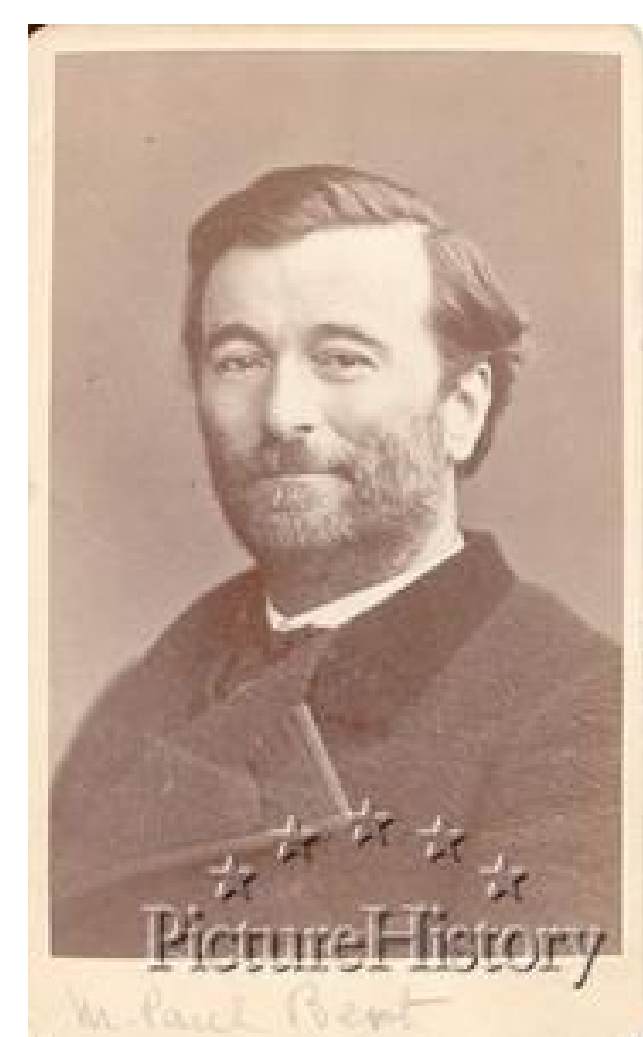


But over the last thirty years, a new group of researchers have begun to question the conventional wisdom that the symptoms of AMS are solely due to hypoxia. 
"the diminution of barometric pressure acts upon the living beings only by lowering the oxygen tension in the air, in the breath, and in the blood which supplies their tissues.... The increase in barometric pressure acts only by increasing oxygen tension in the air and blood...." Paul Bert, 1878.

- Consequently, maintaining sea level equivalent partial pressures of $\mathrm{O}_{2}$ at any and all altitudes we "assume" no signs and symptoms of AMS should be seen. 


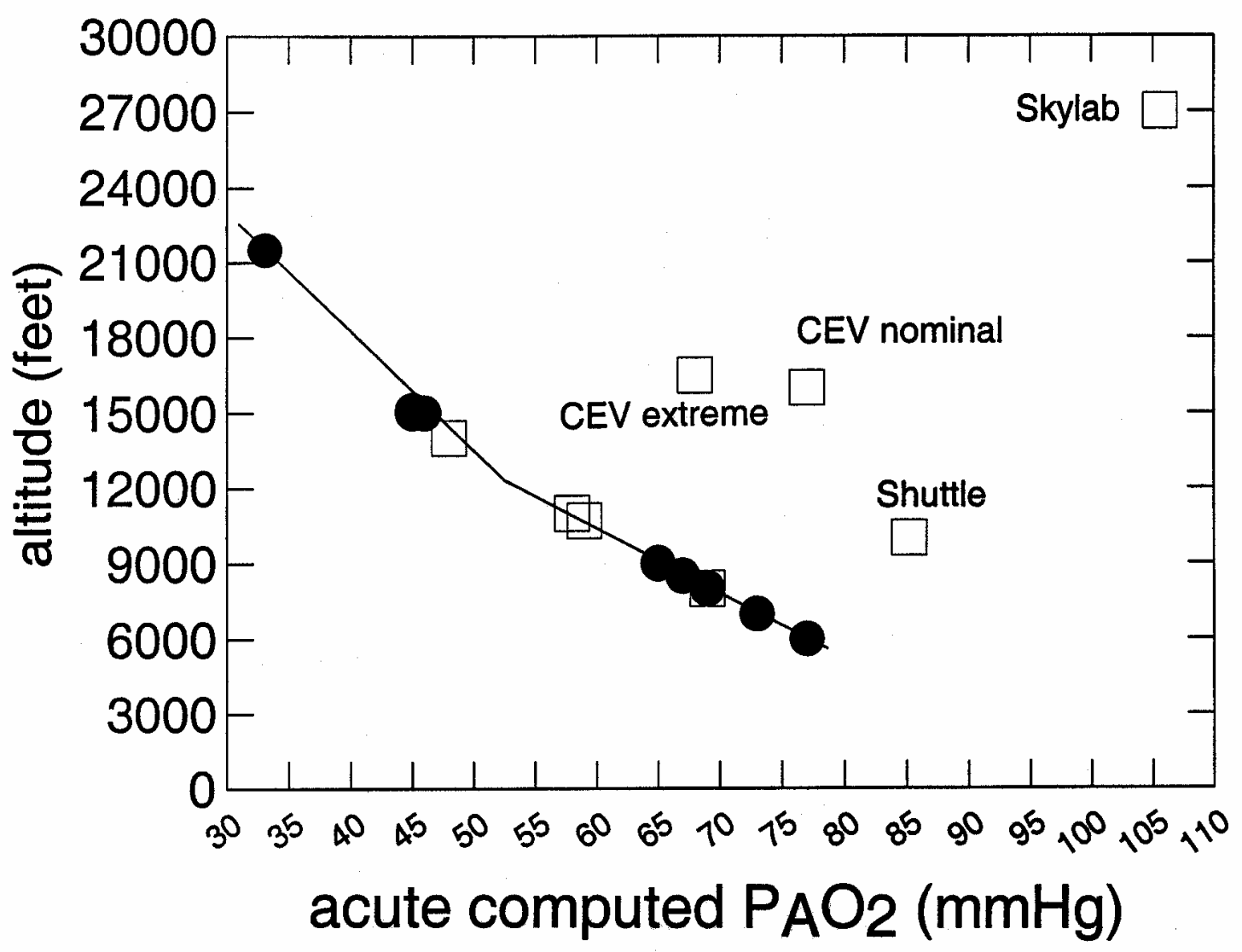

Solid circles connected by the curve are studies done where $\mathrm{HH}$ was induced by ascent to altitude on air, but are $\mathrm{HH}$ exposures without simulated $\mu \mathrm{G}$. The open boxes are exposures where $\mu \mathrm{G}$ adaptation through simulation or actual exposure is present as part of the $\mathrm{HH}$. The two least stressful points along the curve at 6,000 and 7,000 feet are from $\mathrm{Ge}(2002)$ where he shows a slight increase in plasma EP concentration. The third point at 8,000 feet from $\mathrm{Ge}(2002)$ is within the open box from Waligora (1982). 


\begin{tabular}{|c|c|c|}
\hline A & $\underline{B}$ & c \\
\hline 21\%02@760mmHg & $31 \% 02 @ 523$ mmHg & 49\% O2@349mmHg \\
\hline Sea Level & $10,000 \mathrm{ft}$ & $20,000 \mathrm{ft}$ \\
\hline$P_{A} O_{2}=104 \mathrm{mmHg}$ & $P_{A} O_{2}=103 \mathrm{mmHg}$ & $\mathrm{P}_{\mathrm{A}} \mathrm{O}_{2}=104 \mathrm{mmHg}$ \\
\hline
\end{tabular}

Equivalent normoxic air altitudes: $A=B=C$

no AMS is expected?

Variable Pressure with Supposedly Equivalent Hypoxia

\begin{tabular}{|c|c|c|}
\hline$\underline{\mathbf{A}}$ & $\underline{B}$ & $\underline{\mathbf{C}}$ \\
\hline 14\% 02@760mmHg & $21 \% 02 @ 523 \mathrm{mmHg}$ & $32.5 \% 02 @ 349 \mathrm{mmHg}$ \\
\hline Sea Level & $10,000 \mathrm{ft}$ & $20,000 \mathrm{ft}$ \\
\hline $\mathrm{P}_{\mathrm{A}} \mathrm{O}_{2}=61 \mathrm{mmHg}$ & $\mathrm{P}_{\mathrm{A}} \mathrm{O}_{2}=61 \mathrm{mmHg}$ & $\mathrm{P}_{\mathrm{A}} \mathrm{O}_{2}=61 \mathrm{mmHg}$ \\
\hline
\end{tabular}

Equivalent hypoxic altitudes: $A=B=C$ 


\section{- Evaluate multiple hypotheses of cardiopulmonary changes associated with AMS.}

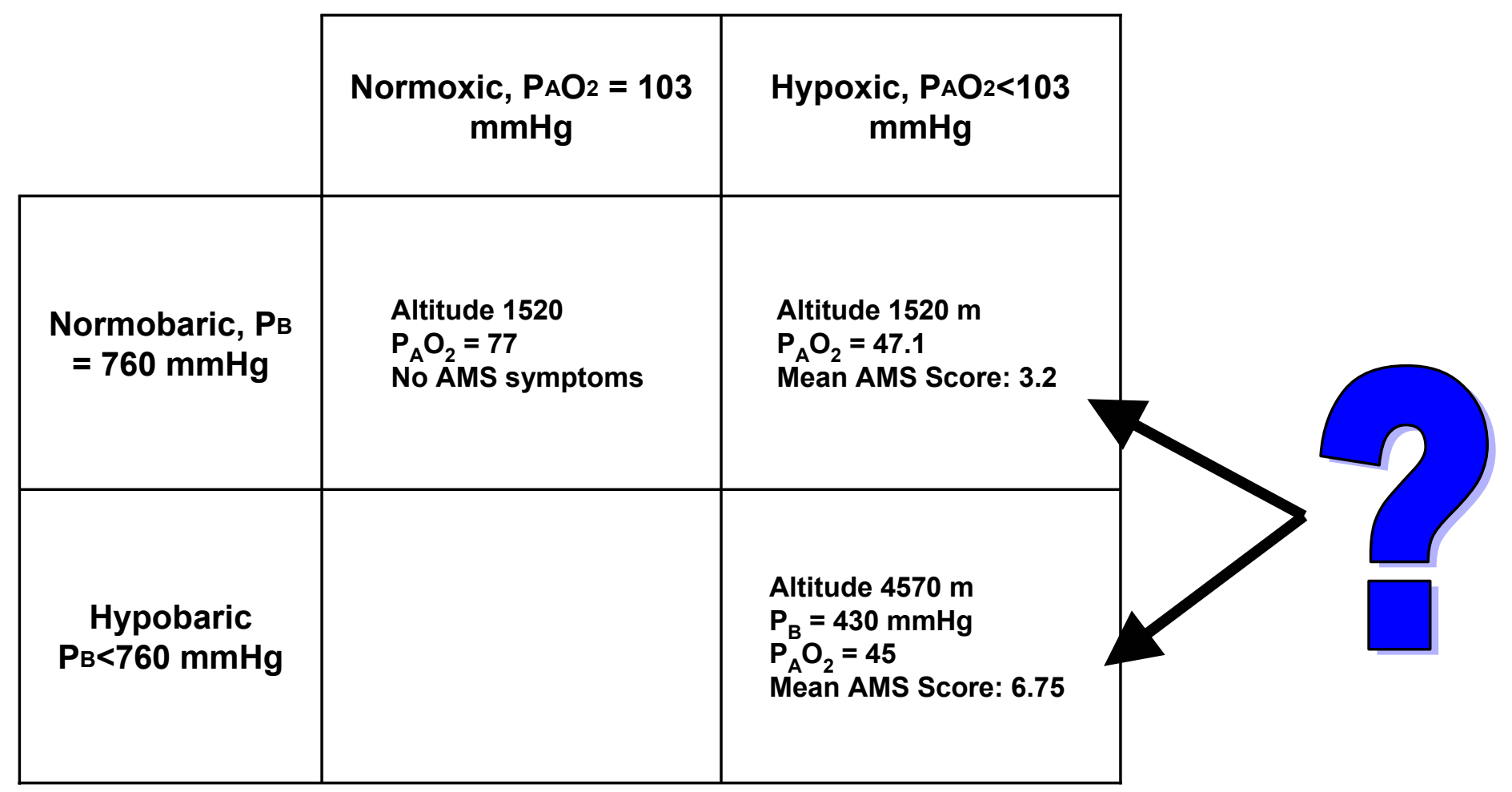




\section{- Document the effect of hypobaria on the pathophysiology of AMS.}

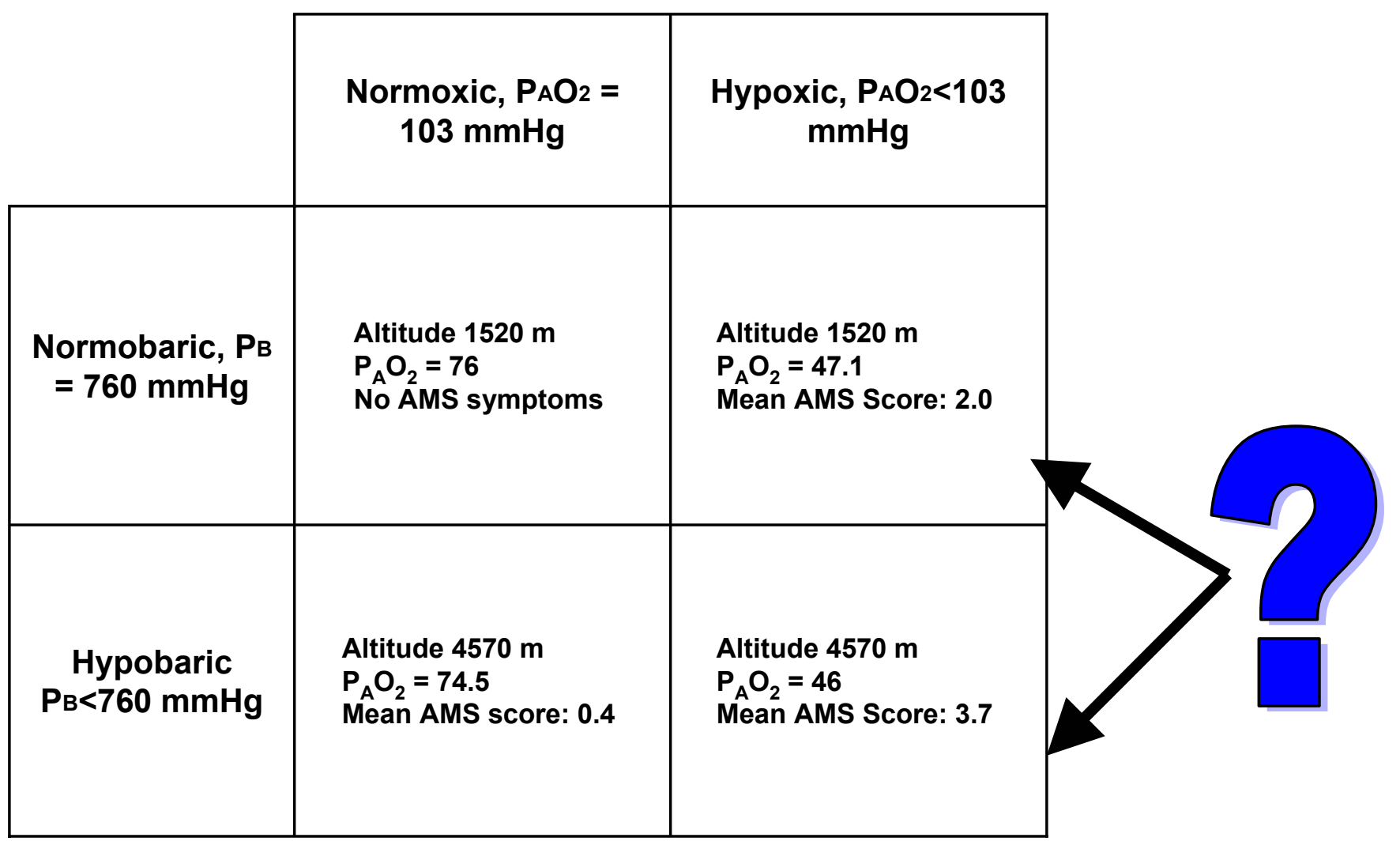

"we found that simulated altitude induces AMS to a greater extent than either normobaric hypoxia or normoxic hypobaria, although normobaric hypoxia induced some AMS." 
- There are few other direct studies on the incidence of AMS in normal versus hypobaric hypoxia.

- Additional research has attempted to define the physiological differences that can be directly related to barometric pressure alone.

- Many of these have left us with more questions then answers. 


\section{Pathophysiology}

- A variety of explanations have been proposed for AMS and the effect of barometric pressure.

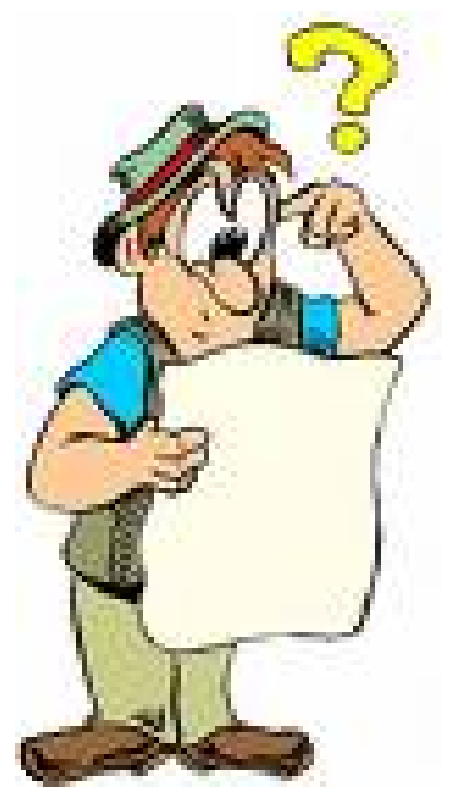


- Decreased gas density relative to 1 ATA

- Decreased quantity of gas in solution relative to 1 ATA

- Increased insensible water loss relative to 1 ATA

- Transient N2 gradient out of tissues

- Potential for VGE
- Gas density at 1 ATA

- Gas in solution at 1 ATA

- Insensible water loss at 1 ATA

- Transient N2 gradient into tissues

- No potential for VGE 
- NASA's past habitats and vehicles rarely exposed the astronaut to hypobaric and hypoxic conditions.

- Staged decompression protocols taking many hours to days with very high $\mathrm{O}_{2}$ levels were used in the past.

- Likelihood of AMS almost nil. 
- Specifies the development of human missions to Earth's moon, Mars and beyond.

- In order to accomplish this task NASA will be required to build an array of vehicles including interplanetary spacecraft, planetary landers, space suits, rovers and surface habitats. 
- Due to the technical, financial and mission operational constraints, the most likely atmospheres of this constellation of habitats, vehicles, suits and rovers will likely be well below standard pressure $\left(P_{B}\right)$.

- Future moon and mars missions with CEV, LSAM and lunar habitat amongst other issues will require efficient EVA egress with minimal prebreathe time while still avoiding DCS and venous gas emboli (VGE).

- This combination of hypobaria with a concomitant hypoxia simulates the conditions encountered by high altitude climbers.

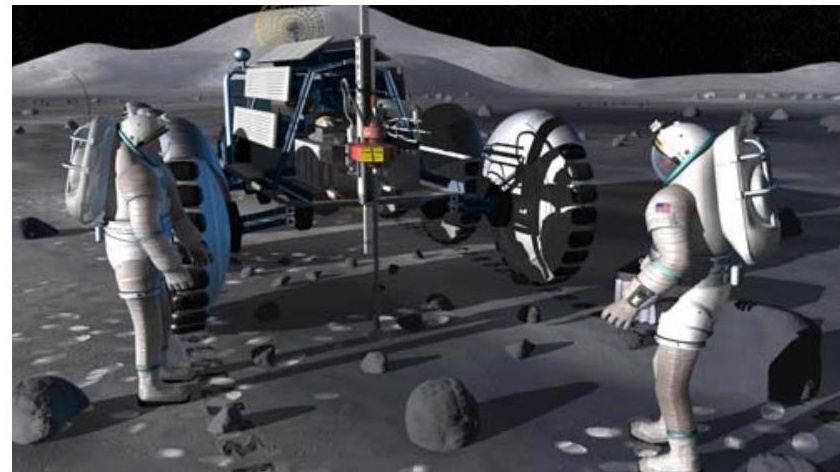


SO.....

Are we putting future astronauts at an increased risk for AMS and all it's associated symptoms? 
- The incidence of AMS as reported in the literature is highly variable.

- Most agree that some people may show mild AMS symptoms as low as $1,981-2,438 \mathrm{~m}(6,500-8,000 \mathrm{ft})$.

- One report claims that as much as $25 \%$ of people may be affected with quick ascent to $1,891 \mathrm{~m}$, with $90 \%$ of symptoms resolving in $3-4$ days.

- Houston C.S. claims that $25-30 \%$ of people ascending to $3,048 \mathrm{~m}$ $(10,000 \mathrm{ft})$ will experience some type of AMS, this figure will double at $4,200 \mathrm{~m}$ and almost all people will show some signs of AMS by $5,486 \mathrm{~m}(18,000 \mathrm{ft})$.

- Roach et al 1998 that a small percentage, $5 \%$ of people who develop AMS at 3,962m (13,000 ft) will go on to develop life threatening HAPE and/or HACE. 
- Based on extrapolation of current research it does not seem likely that one may experience severe AMS.

- The bigger issue is likely Performance.

- The bigger issue is a mitigation plan. 
- Will the performance of future astronauts be effected?

- Can we still maintain a quick egress for EVA while safely balancing engineering, mission control, DCS, and AMS with minimal prebreathe times?

- What minimum $\mathrm{P}_{A} \mathrm{O}_{2}$ can we maintain to satisfy all the above? 
- There have been almost no direct studies on the effect of AMS on performance.

- Montgomery in 1989 stated that the incidence of AMS at $1,981 \mathrm{~m}(6,500 \mathrm{ft})$ was approximately $12 \%$ and further stated that

- He did not go as far as to quantify a decrease in effective performance during this study. 
- If it is determined that AMS is an acceptable risk for future space flight, a plan of treatment must be established.

- Mild AMS is treated by:

- Halting ascent

- Await acclimatization

- Acetazolamide (125-250 mg BID)

- $\mathrm{O}_{2}$ therapy; .05-1.0 l/min mask or cannula: 
- The best predictor of AMS is history of prior episode

- Acetazolamide has proven effective for AMS prophylaxis

- Roach et al. 1998 showed "development of AMS was significantly and negatively correlated with $\mathrm{S}_{2} \mathrm{O}_{2} \%$ ".... "subjects with $\mathrm{S}_{2} \mathrm{O}_{2} \%$ above $84 \%$ appear immune to developing AMS at the altitudes tested." 


\section{Actions of acetazolamide}

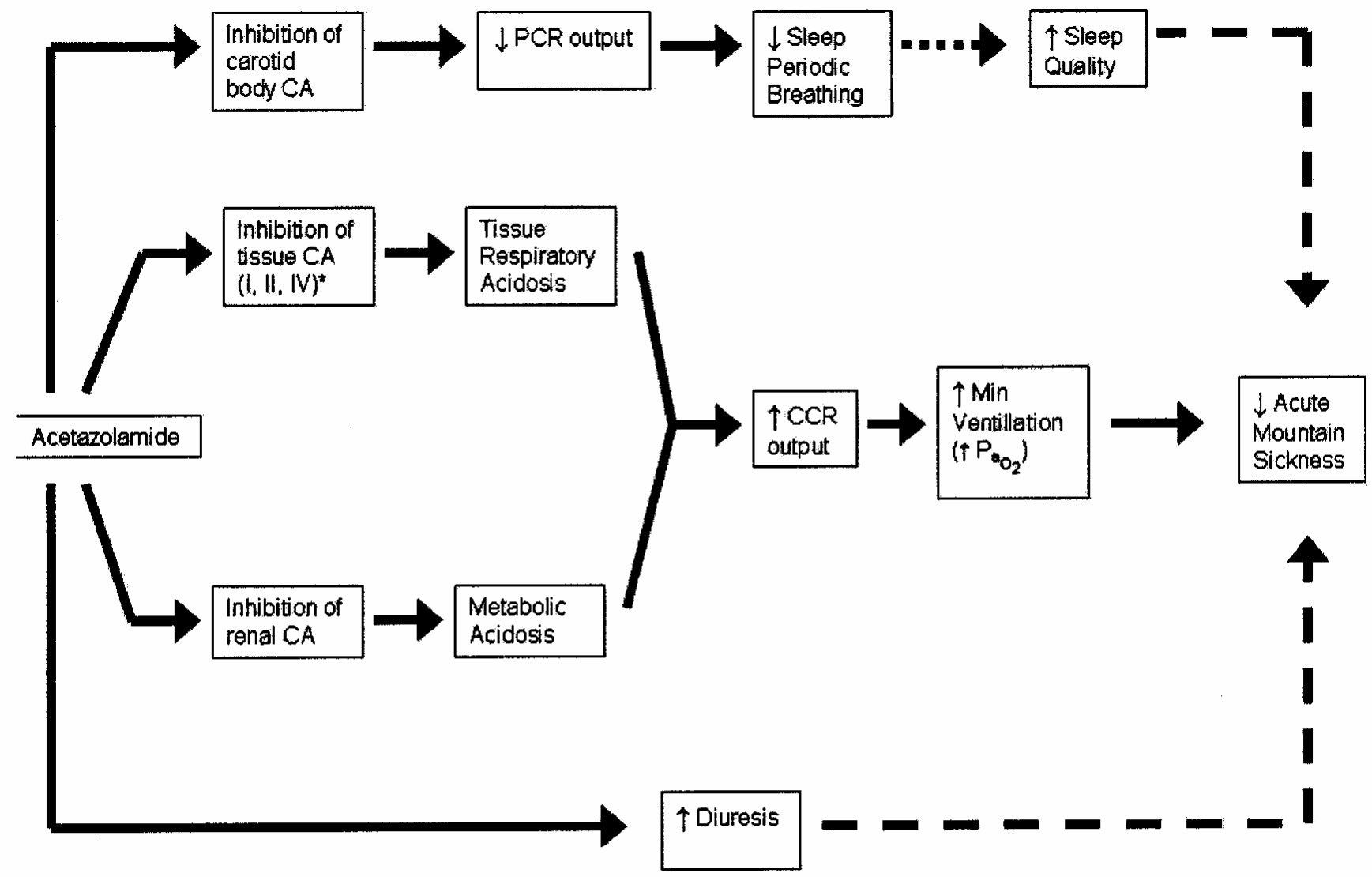

Figure 5. Proposed model for acetazolamide's reduction of AMS. Solid lines represent well-established connections; broken lines represent less-well established connections. * CA I and II are located intracellularly in RBCs and tissues; CA IV is located on the luminal aspect of nearly all capillary beds. $\mathrm{PCR}=$ Peripheral Chemoreceptor; $\mathrm{CCR}=$ Central Chemoreceptor. 
- Potential negative synergy between mild hypoxia and adaptation to $\mathbf{m G}$.

- Does $\mathrm{mG}$ change the incidence of AMS?

- redistribution of lung fluid

- increased interstitial edema

- altered incidence of HAPE? 


\section{Optimum HCT for $\mathrm{O} 2$ transport}

Relationship between haematocrit and blood viscosity

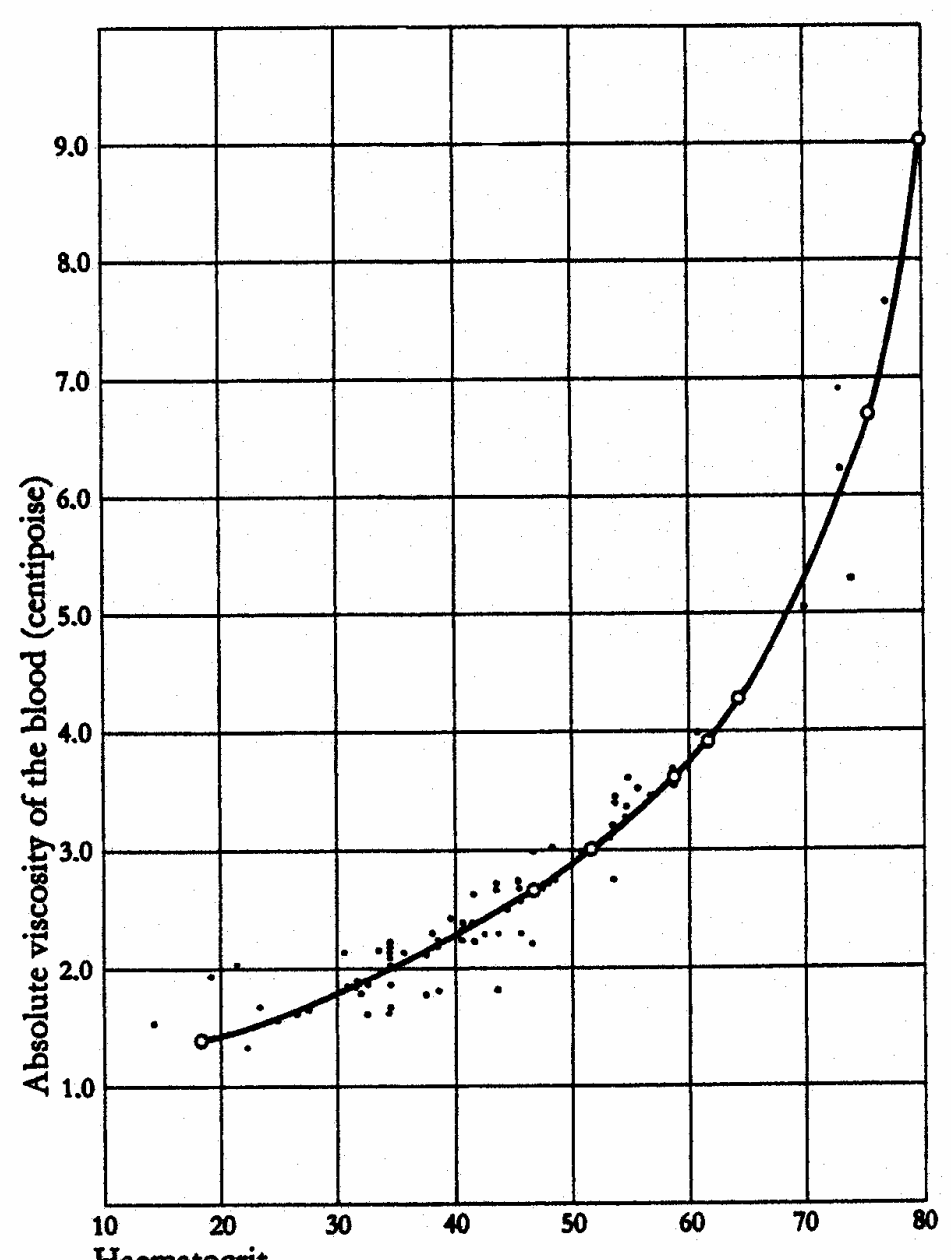

A

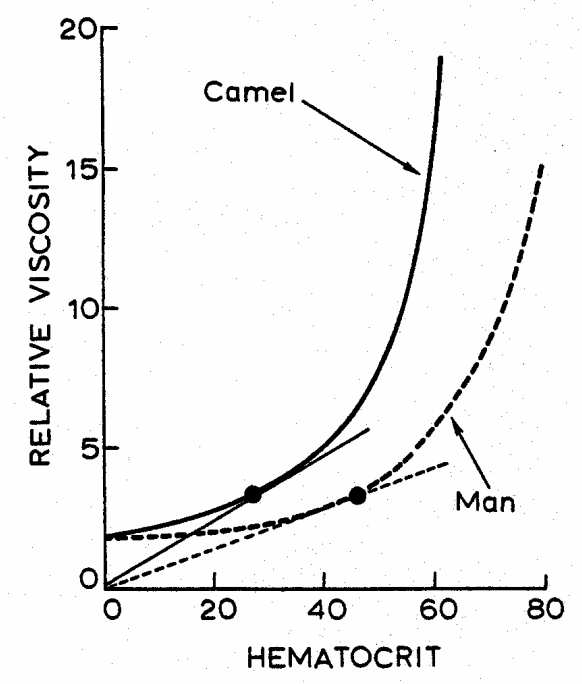

B

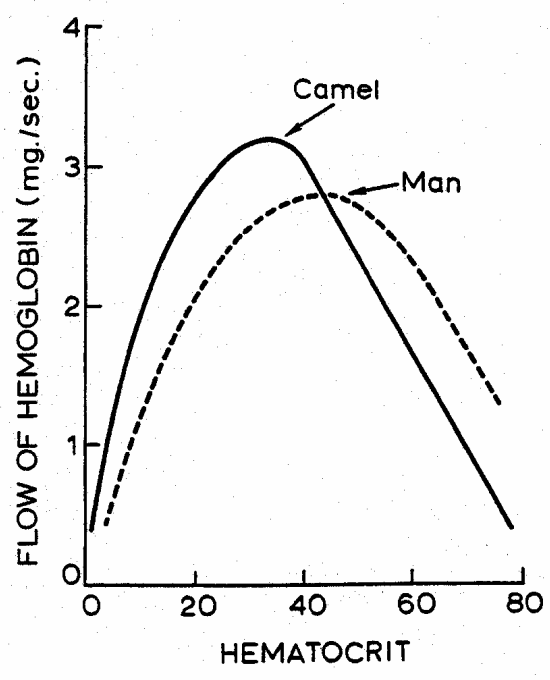

Fig. 5-5. A, relative viscosity vs hematocrit for human blood and camel blood. B, the transport of oxygen through a glass tube vs hematocrit, with a constant driving pressure. 
- Unique experiments duplicating the atmospheres and conditions for the proposed CEV, LSAM, Habitats and EVA suits.

- Determine who may be at risk for developing AMS and it's effects on that individual.

- Current knowledge does not allow us to predict those that are at risk for AMS, the best predictor is previous episodes.

- Do we select future astronauts based on criteria to reduce the risk? 


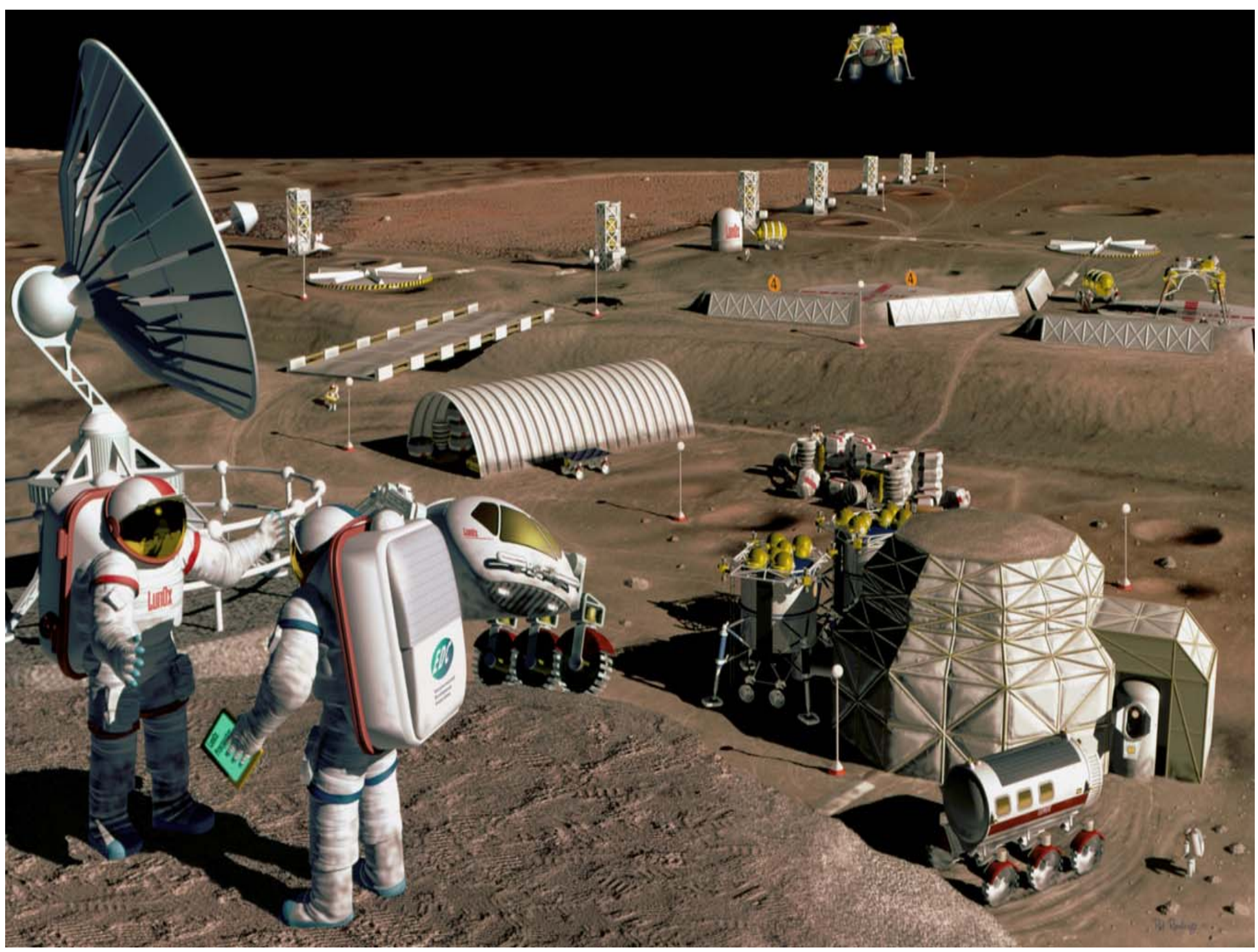

